\title{
The Global Fund to Fight AIDs, Tuberculosis and Malaria: The Journey of a Public-Private Partnership
}

\author{
Fady Zeidan and Jean Abboud*
}

\begin{abstract}
The Global Fund to Fight AIDs, Tuberculosis and Malaria (Global Fund) is a unique multilateral institution: originally conceived as a public-private partnership, it was established as a not-for-profit foundation under Swiss law, before gradually evolving into an international organization. The Global Fund Secretariat is based in Geneva and is composed of some 780 employees. This chapter examines the role international administrative law has played in the effective and efficient functioning of the Global Fund. The genesis of the Global Fund, its institutional features and governance structures are presented in Section 1 and the initial administrative arrangements concluded between the Global Fund and the World Health Organization to enable the Global Fund to conduct its operations are discussed in Section 2. Sections 3 and 4 examine the internationalization of the status of the Global Fund through the prisms of the privileges and immunities of the organization and its officials, and the resolution mechanisms of employment-related disputes, respectively. Considerations regarding the legal framework applicable to Global Fund employees are also addressed.
\end{abstract}

The Global Fund to Fight AIDs, Tuberculosis and Malaria (Global Fund) was created in 2002 following a recognition by the international community that a joint and novel effort was necessary to combat Human Immunodeficiency Virus (HIV)/Acquired Immunodeficiency Syndrome (AIDS), tuberculosis and

* Fady Zeidan, General Counsel and Head of the Legal and Governance Department of the Global Fund to Fight AIDs, Tuberculosis and Malaria (Global Fund), fady.zeidan@theglobalfund.org; Jean Abboud, Principal Legal Counsel, Legal and Governance Department of the Global Fund, jean.abboud@theglobalfund.org. The views expressed in this presentation are those of the authors and do not necessarily reflect the views of the Global Fund. 
malaria which had reached historical heights of infection at the turn of the millennium. The nascent stages underlying the creation of the Global Fund go back to the Group of Eight (G8) summit held in Okinawa, Japan in 2000. ${ }^{1}$

In April 2001, at the African Summit on HIV/AIDS, Tuberculosis and Other Infectious Diseases, Kofi Annan, the then Secretary General of the United Nations (UN), proposed the creation of a global fund "dedicated to the battle against HIV/AIDS and other infectious diseases". ${ }^{2}$ Interestingly, he alluded in his remarks to the public-private nature of this new structure when he noted that the fund,

must be structured in such a way as to ensure that it responds to the needs of the affected countries and people. And it must be able to count on the advice of the best experts in the world - whether they are found in the United Nations system, in governments, in civil society organizations, or among those who live with HIV/AIDS or are directly affected by it. ${ }^{3}$

Shortly thereafter, in June 2001, the UN General Assembly called for the,

establishment, on an urgent basis, of a global HIV/AIDs health fund to finance an urgent and expanded response to the epidemic [mobilizing contributions] from public and private sources, with a special appeal to donor countries, foundations, the business community, including pharmaceutical companies, the private sector, philanthropists and wealthy

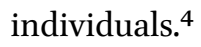

Immediately after the adoption of the Declaration of Commitment on HIV/AIDS, the G8 countries expressed in Genoa, in July 2001, their determination "to make the fund operational before the end of the year" and committed USD1.3 billion. Interestingly again, the G8 countries noted that the fund will be a "public-private partnership" and called "on other countries, the private sector, foundations and academic institutions to join with their own contributionsfinancially, in kind and through shared expertise". 5

1 G8 Communiqué Okinawa 2000.

2 Annan, 26 April 2001.

3 Ibid.

4 UNGA Res S-26/2, 27 June 2001, Annex, para 90.

5 G8 Communiqué Genova 2001. 
Given the urgent need to mobilize resources and initiate large-scale financial disbursements to fight the three diseases - in support of the attainment, initially, of the Millennium Development Goals - a Transitional Working Group, established in July 2001, decided in December 2001 to incorporate the fund in Switzerland and conclude agreements with the World Bank, as the trustee, and the World Health Organization (WHO), as the support service provider. This recommendation was acted upon and the Global Fund was registered as a not-for-profit foundation under Swiss law on 24 January 2002, holding its first Board meeting four days thereafter. At the time, it was considered that this approach would help to speedily implement the public-private partnership nature of the nascent institution consistent with the desire expressed by the UN General Assembly in the Declaration of Commitment on HIV/AIDS and avoid the delays usually associated with the establishment of a traditional international organization. Reflecting the urgency for the Global Fund to start its operations, the Board of the Global Fund approved in April 2002 the first round of grants. ${ }^{6}$

Since its inception, the core principles, governance structures and modus operandi of the Global Fund have substantially remained the same. Indeed, there are four core principles based on which the Global Fund operates, namely: partnership; country ownership; performance-based financing; and transparency. ${ }^{7}$ The idea underlying the first principle is that governments, civil society, communities affected by the diseases, technical partners, the private sector, faith-based organizations and other funders must work together and be involved in the decision-making process to achieve impact. Country ownership is based on the recognition that local experts are best placed to structure programs and implement grants; as such, countries design, lead, make investment decisions and manage their programs. More generally, on-going financing depends upon performance and proven results and a high degree of transparency is adhered to in all Global Fund work including applications for funding, funding decisions, grant performance, results, governance and oversight.

These core principles are visible in the governance structures of the Global Fund and in its operational model. Indeed, the highest governing body of the Global Fund is the Global Fund Board which is currently composed of 20 voting constituencies and eight non-voting members, representing mainly the technical partners with whom the Global Fund works. ${ }^{8}$ The voting constituencies are divided into two groups-namely, on the one hand, the donor group,

6 The Global Fund, Board Decision GF/Bo2/DPo6.

7 The Global Fund, 'The Framework Document' 2001.

8 The Global Fund, Bylaws, art 7.1. 
which consists of eight donor country representatives, one private sector representative and one private foundations representative; and, on the other hand, the implementer group which encompasses seven developing country representatives, two nongovernmental organization (NGO) representatives and a representative of an NGO who is a person living with HIV/AIDS or from a community living with tuberculosis or malaria. ${ }^{9}$

The Board's composition reflects, in this sense, the partnerships between donor and recipient governments, civil society, the private sector, private foundations, communities affected by the diseases and the technical partners, on which the Global Fund is based. To strengthen further the balance between the various stakeholders, the Board's decisions require the support of a qualified two-thirds majority of the constituencies of each group to pass. These features are also present in the structures and charters of the Board's standing committees-namely, the Strategy Committee, the Audit and Finance Committee and the Ethics and Governance Committee-and represent a marked evolution from the traditional multilateral model where each State receives an equal vote, but also from the development bank model where shareholders hold votes in proportion to their financial participation.

The Global Fund raises and invests nearly USD 4 billion a year to support programs in more than 100 countries. The money, which is raised in replenishment conferences held every three years, comes in a predominant proportion from governmental donations and, to a lesser extent, from non-governmental donations. Broadly speaking, the money raised by the Global Fund is transformed into grants and allocated to recipient countries to respond to the plans developed by each country coordinating mechanism to fight the diseases in a given country. These plans are reviewed by an independent panel of experts to determine if they will achieve the envisaged results. Once finalized, the plan is submitted to the Global Fund Board for approval and local experts and partners can start using the grant money to deliver programs and implement the plans. The programs and grants are continuously monitored by local fund agents and subject to the audits and investigations conducted by the Office of the Inspector General. ${ }^{10}$

Each constituency can be formed by one or more members. See full list of constituencies available at <https://www.theglobalfund.org/en/board/constituencies/> accessed 28 November 2019. The seven developing country seats are allocated to six constituencies based on each of the six wHO regions and to an additional constituency from Africa. The wно has no role in selecting Board Members. WHO regions are used only as a reference for aggregating developing countries into regional groups. 
Prior to the establishment of the Global Fund, the wHO and the Swiss Government submitted a joint proposal to host the Global Fund in Geneva. The wHO promised to provide administrative services to the Secretariat through a unit dedicated solely to the support of the Global Fund and the Swiss Government contributed to the establishment of the Secretariat in Geneva and committed to provide the Global Fund over time with certain tax exemptions and other benefits.

As such, shortly after its establishment in Switzerland, the Global Fund concluded, in May 2002, an Administrative Services Agreement (ASA). ${ }^{11}$ The officials hired to work for the Global Fund were employed by the wHo, in accordance with the WHo's Staff Regulations, and thereafter assigned to Global Fund projects. Through this arrangement, the Global Fund formally had no employees of its own but maintained a legal personality and governance structures distinct from the WHO's. And while the Global Fund had no privileges and immunities until 2004 (see Section 3 below), wHo employees assigned to the Global Fund projects enjoyed the privileges and immunities, not only as defined in the Agreement concluded between the Swiss Federal Council and the wHO to determine the legal status of this organization in Switzerland, but also, more broadly, under the Convention of 21 November 1947 on the Privileges and Immunities of the Specialized Agencies. ${ }^{12}$ In conjunction with this agreement, and notably to ensure the funds contributed to the Global Fund could be efficiently held and managed, and also benefit from immunities from execution and jurisdiction consistent with funds held by multilateral organizations, a Trustee Agreement was entered into between the Global Fund and the World Bank in May 2002. This arrangement, with some amendments, remains applicable today.

Some five years after the conclusion of the ASA, the Global Fund Board decided in November 2007, that the Global Fund would discontinue the ASA with the WHO not later than December 2008, and that new administrative and employment arrangements would be put in place. ${ }^{13}$ Accordingly, when the ASA was terminated in 2008, wHO officials assigned to Global Fund projects were simultaneously offered contracts of employment directly with the Global Fund and a Human Resources Policy Framework (HRPF), effective as of 1 January

\footnotetext{
11 The Global Fund, Board Decision GF/Bo2/DP1o.

12 Specialized Agencies Convention.

13 The Global Fund, Board Decision GF/B16/DP21.
} 
2009, was adopted by the Board to cater to the Global Fund's administrative autonomy from the WHO. ${ }^{14}$

The HRPF defined a new compensation and benefits package for the Global Fund, which would differ from the wHo's in several ways. In view of these changes, to avoid imposing any material financial disadvantage on staff as a result of their transfer from the wHO to the Global Fund, the HRP F committed that wHO staff would not be disadvantaged by the transition to the new compensation and benefits package. To fulfill this commitment, the Secretariat adopted a set of grandfathering rules, which were incorporated by reference to Global Fund employment contracts signed by staff transferring from the wHO, which identified certain wHO benefits that would remain in effect for such staff and provided a time-limited compensation mechanism to cover individual cases where the package on offer by the Global Fund would prove less advantageous compared to the package offered by the wHo. The new employment contracts were effective as of 1 January 2009 .

While the termination of the ASA broadened the Global Fund's autonomy and flexibility to fulfill its mandate, one consequence was the loss of privileges and immunities enjoyed by former WHO officials under the Convention on the Privileges and Immunities of the Specialized Agencies.

\section{$3 \quad$ Privileges and Immunities of the Global Fund}

In addition to the privileges and immunities enjoyed by wHO employees assigned to Global Fund projects under the Convention on the Privileges and Immunities of the Specialized Agencies, Switzerland and the United States had granted, in 2004 and 2006 respectively, privileges and immunities, prior to the Global Fund's separation from the wHO.

Indeed, shortly after the initial establishment of the Global Fund as a Swiss foundation, the Global Fund Board considered options regarding the future legal status of the Global Fund; namely, to keep status quo, to expand the immunities of the Global Fund by way of a headquarters agreement, to move to the status of an independent international organization or to become a specialized institution within the United Nations. Among these options, the expansion of the privileges and immunities through a headquarters agreement was considered the most optimal way forward..$^{15}$ At the time, it was noted that the Global Fund was "engaged in high-risk activities of a scope and scale

14 The Global Fund, Board Decision GF/B17/EDPo8/16.

15 The Global Fund, 'Report of the Governance and Partnership Committee' 2003, pt 6. 
typically undertaken only by international organizations and governments, and that it [was] exposed to potential legal liabilities that are significant". ${ }^{16}$ The conclusion of a headquarters agreement was seen therefore as a significant step to protect the Global Fund in Switzerland against liabilities that may arise based on its activities. ${ }^{17}$

As such, the Global Fund and the Swiss Federal Council concluded in 2004 a Headquarters Agreement which recognizes the international juridical personality and legal capacity of the Global Fund in Switzerland and provides to the Global Fund a similar set of privileges and immunities as those enjoyed by other international organizations in Switzerland. ${ }^{18}$ The Global Fund was also designated - by President George W. Bush in 2006 pursuant to Executive Order 13395 - as a public international organization entitled to enjoy the privileges, exemptions and immunities under the International Organizations Immunities Act ${ }^{19}$ in the United States.

However, following its separation from the wHO, the only set of protections that applied to the Global Fund, its officials and assets were those granted by Switzerland and the United States, and the protection afforded to its funds under the trusteeship of the World Bank. Against this background and in recognition of the significance of this consequence, a working group of legal experts was convened shortly after the separation from the wHо to develop an instrument - the Agreement on Privileges and Immunities (P\&I Agreement) to enable countries to grant privileges and immunities to the Global Fund and to recognize its legal personality beyond its original anchor as a Swiss foundation. The Global Fund Board affirmed the importance of privileges and immunities, acknowledging the challenges and risks faced by Global Fund and its staff without such protections, and formally called upon States, in December 2009, to consider granting privileges and immunities to the Global Fund through either the P\&I Agreement or domestic laws. ${ }^{20}$

16 The Global Fund, 'Report of the Governance and Partnership Committee' 2004, pt 4.

17 Ibid. The options of maintaining status quo or becoming a quasi-governmental organization were considered to present limited benefits that were outweighed by a number of disadvantages. The options of becoming an intergovernmental organization or a specialized institution within the United Nations were considered burdensome, given treaty making formalities, and less appropriate as the private sector and NGO members of the Global Fund Board would not be able to be party to the treaty creating the Global Fund and the Global Fund was never intended to be part of the United Nations system. See, the Global Fund, 'Report of the Governance and Partnership Committee' 2003, pt 6.

18 Agreement between the Swiss Federal Council and the Global Fund.

19 US Executive Order 13395, 13 January 2006.

20 The Global Fund, Board Decision GF/B2o/EDPo4. 
Under the P\&I Agreement - which entered into force in April 2019 following the deposit of the 1oth ratification instrument by Senegal-the Global Fund is afforded juridical personality; Global Fund assets, income and property, wherever located, are immune from all forms of legal process; and officials, representatives of States and other persons constituting the organs of the Global Fund, members of technical groups or other experts are granted privileges and immunities broadly similar to those granted to such officials of other international organizations. ${ }^{21}$

As a result of the entry into force of the P\&I Agreement, the Global Fund now enjoys privileges and immunities in some 15 countries; namely, the countries that ratified the P\&I Agreement, in addition to Switzerland and the United States. $^{22}$

\section{$4 \quad$ Resolution of Employment Disputes}

Prior to the termination of the ASA with the wHo, the Global Fund applied to recognize the jurisdiction of the Administrative Tribunal of the International Labour Organization (ILOAT). Considering the eligibility criteria for membership set out in the Tribunal's Statute, the Global Fund outlined in its request its compliance with the criteria and highlighted, in this regard, its international character by referring to the Headquarters Agreement concluded with the Swiss Federal Council and its designation as an international organization in the United States. ${ }^{23}$ The Global Fund also underscored that it is exempt from applying national law in its relations with its employees and enjoys immunity

21 The Global Fund, 'Global Fund Agreement on Privileges and Immunities Enters into Force', 17 April 2019.

22 Burkina Faso, Eswatini, Ethiopia, Georgia, Liberia, Malawi, Moldova, Mozambique, Rwanda, Senegal, Togo, Uganda and Zimbabwe. A small number of countries, Burundi, Côte d'Ivoire, Gabon, Ghana, Montenegro and Niger have already signed the P\&I Agreement, but the process of ratification is still ongoing.

23 ILOAT Statute, art II, para 5 and related annex ("To be entitled to recognize the jurisdiction of the Administrative Tribunal of the International Labour Organization in accordance with paragraph 5 of article II of its Statute, an international organization must either be intergovernmental in character, or fulfil the following conditions: (a) it shall be clearly international in character, having regard to its membership, structure and scope of activity; (b) it shall not be required to apply any national law in its relations with its officials, and shall enjoy immunity from legal process as evidenced by a headquarters agreement concluded with the host country; and (c) it shall be endowed with functions of a permanent nature at the international level and offer, in the opinion of the Governing Body, sufficient guarantees as to its institutional capacity to carry out such functions as well as guarantees of compliance with the Tribunal's judgments"). 
from legal process under its Headquarters Agreement. It also observed that it has a permanent governance structure and its Board accepted that awards rendered by the ILOAT are chargeable to the Global Fund budget - thereby ensuring compliance with such awards-and added that "Global Fund staff members expressed support for the use of the ILOAT as it is the dispute settlement mechanism employees are already familiar with and trust". ${ }^{24}$ In November 2008 , the request was approved by the International Labour Organization Governing Body and the ILOAT became the final arbiter for the resolution of employment-related disputes at the Global Fund. In this respect, the admission of the Global Fund to the Tribunal's jurisdiction and the conferral, on the same year, of observer status for the Global Fund to participate in the sessions and works of the United Nations General assembly represent additional steps in the evolution of the Global Fund into an international organization. ${ }^{25}$

As is often the case in other international organizations, employees must exhaust the internal means of redress prior to submitting a complaint before the ILOAT. To that effect, an employee must first file a grievance through a request for resolution which is reviewed by the Head of Human Resources. If the employee is dissatisfied with the response from the Head of Human Resources, they can challenge the same before the Appeal Board. The appeal is reviewed by a panel composed of an independent Chair and two peer colleagues. After the appeal process, a recommendation of the Appeal Board is submitted to the Executive Director who has the option to accept or reject it, and the employee may then decide to challenge the final decision of the Executive Director before the iLOAT. Apart from the formal internal mechanism, informal mechanisms for the resolution of employment-related disputes are also made available to staff, including a staff counselor, an ombudsman and mediation services.

Since the recognition of the jurisdiction of the ILOAT in 2008, to date, the ILOAT has rendered more than 30 judgments in relation to complaints brought by Global Fund employees on a wide variety of topics, regarding, among other things, termination of appointments (as a result of restructurings, unsuccessful probations, disciplinary cases), performance evaluations, modifications of salary and grading structures, and eligibility for benefits under specific Global Fund policies.

24 International Labour Office, 'Matters relating to the Administrative Tribunal of the ILO', November 2008, Appendix.

25 UNGA Res 64/122, 16 December 2009. 
Some of the cases were brought by former wHO officials alleging acquired rights considerations under the above-mentioned grandfathering rules. ${ }^{26}$ By way of example, some former wHO officials challenged the decision of the Global Fund to reduce the expatriate premium starting 1 January 2015. The progressive reduction was spelled out in the HRPF adopted by the Board shortly prior to the separation from the WHO and the employees were informed at the time of the progressive phasing out of this benefit. The employees sought however to have the expatriate premiums maintained at $100 \%$ without any reductions for the period of employment with the Global Fund based on an alleged breach of the Global Fund grandfathering rules. The ILOAT, however, rejected the complaints filed by these employees. ${ }^{27}$ Similarly, the challenge by a former WHO official to the decision of the organization to make changes to the grading system and salary structure was not successful. The employee in question argued, among other things, that the implementation of the revisions constituted a breach of the commitments of the Global Fund under the grandfathering rules and thereby caused injury to him. The ILOAT rejected this argument and found that there was no evidence to support an allegation regarding an immediate or future injury to the employee as a result of the adoption of the revisions. The Tribunal noted in that respect that the complainant continued to hold the same title and responsibilities even if the nomenclature of their grade level changed. ${ }^{28}$

More generally, it has been observed that since its separation from the wHO in 2009, the Global Fund "has been trying to define its identity oscillating

26 While international organizations may amend the employment conditions of their staff members, they must take into account the general legal principle of acquired rights. According to the ILOAT, "the amendment of a rule to an official's detriment and without his consent amounts to breach of an acquired right when the structure of the contract of appointment is disturbed or there is impairment of any fundamental term of appointment in consideration of which the official accepted appointment" (see ILOAT, Ayoub et al. v International Labour Organisation 1987, consid 13). The Tribunal determines whether the altered term is fundamental and essential by assessing the nature of the altered term, the reason for the change and the consequences and effects of the change (consid 14).

27 ILOAT, R. M. (No 2) v Global Fund 2018; ILOAT, D. v Global Fund 2019. The Tribunal noted in consideration of 11 of D. $v$ Global Fund 2019 that the complainant "provided no evidence to prove that by reducing the expatriate premium [...], the Global Fund breached its commitment to her under the 'grandfathering' clause. [The complainant did not show] how the reduction 'created a financial prejudice' to her by reference to the overall value of the benefits and allowances she received as a wHO staff member. In other words, she has not explained how the reduction of the expatriate premium as from January 2015 breached her guaranteed retention of the total value of the benefits and allowances to which she was entitled under the pre-existing conditions as a wHO staff member". 
between its affinities with the private sector and its history with the wHO". 29 Indeed, while on the one hand, the work of the Global Fund is guided by a clear mission with specific targets and deadlines aiming to end the three diseases as public health threats by 2030 and a strong emphasis is put on agility, flexibility and differentiation, to ensure value for money for the beneficiaries of Global Fund grants and for the donor government, non-government and private sector contributors, on the other hand, the main features of the Global Fund's disputes resolution mechanism resemble those of other United Nations-type intergovernmental organizations. These contrasts are also reflected in the Tribunal's jurisprudence. Indeed, while the Tribunal recognized that the Global Fund was a public-private partnership with a "unique international legal personality" 30 and rejected the application of the Noblemaire principle to the Global Fund as it is not part of the UN Common system, ${ }^{31}$ the Tribunal sanctioned the Global Fund when it considered that it disregarded some general principles of international administrative law applicable to international organizations. ${ }^{32}$

By and large, the journey of the Global Fund has been a successful one. Health programs supported by the Global Fund partnership have saved $3^{2}$ million lives and overall, the number of deaths caused by AIDs, tuberculosis and malaria each year has been reduced by $40 \%$ since 2002 in countries where the

29 Otis 2016.

$30 \quad$ ILOAT, C. C. v Global Fund 2014, consid 2.

31 The Tribunal provided the following observations on the Noblemaire principle in $B$. (No 2) v Global Fund 2018, consideration 12, "the Noblemaire principle, which dates back to the days of the League of Nations and which the system of the United Nations took over, embodies two rules. One is that, to keep the international civil service as one, its employees shall get equal pay for work of equal value, whatever their nationality or the salaries earned in their own country. The other rule is that in recruiting staff from all Member States, international organisations shall offer pay that will draw and keep citizens of countries where salaries are highest. However, it is a principle that generally has been applied to organisations which participate in the United Nations common system". The Tribunal concluded in the same paragraph, "It cannot be assumed, as the complainant seems to suggest, that the Noblemaire principle should be grafted on to those legal arrangements notwithstanding that the Global Fund is not part of the common system. The Tribunal rejects the suggestion it should be".

32 IlOAT, M. F. A. A. v Global Fund 2015, consid 13; ILOAT, J. (No 2) v Global Fund 2019, consid 15 . 
Global Fund invests. ${ }^{33}$ As an embodiment of the efforts of the international community to develop fora suitable to reinvigorate multilateral engagement, the Global Fund complements the mandate of existing treaty-based institutions and has aimed to develop a specific approach to institutional governance based on its unique model of operation.

The Global Fund reflects the example of a novel multilateral organization seeking to increase its efficiency and to maximize its impact while operatingdue in large part to the non-application of national employment laws, to the immunity of the organization from national courts and the international civil servant character of its employees - within the confines of traditional employment dispute resolution mechanisms and international administrative law. Since the inception of the Global Fund, international administrative law has played a central role whether through the administrative arrangements concluded with the WHO, the recognition of the jurisdiction of the ILOAT, or the continuous strengthening of the Global Fund's employment-related processes and frameworks in support of the achievement of the overall strategy of the organization. The law of employment relations will certainly continue to play an important role within the next years of the Global Fund's mission to end the epidemics of HIV/AIDS, tuberculosis and malaria by 2030. ${ }^{34}$

\section{Reference List}

Agreement between the Swiss Federal Council and the Global Fund to Fight AIDs, Tuberculosis and Malaria in view of determining the legal status of the Global Fund in Switzerland (The Global Fund) <https://www.theglobalfund.org/media/3375/ bmo7_07gpcreportannex92_annex_en.pdf?u=636486806830000000 > accessed 21 November 2019.

Annan K, 'Address by Kofi Annan to the African Summit on HIV/AIDs, Tuberculosis and Other Infectious Diseases' (African Summit, Abuja, 26 April 2001) <https:// www.un.org/sg/en/content/sg/speeches/2001-04-26/address-kofi-annan-africansummit-hivaids-tuberculosis-and-other> accessed 28 November 2019.

B. (No 2) $v$ Global Fund to Fight AIDS, Tuberculosis and Malaria, ILOAT Judgment No 3921 (2018).

C. C. $v$ Global Fund to Fight AIDS, Tuberculosis and Malaria, ILOAT Judgment No 3247 (2014).

33 The Global Fund, 'Results \& Impact'.

34 The Global Fund, 'The Global Fund Strategy 2017-2022'. 
Convention on the Privileges and Immunities of the Specialized Agencies (adopted 21 November 1947, entered into force 2 December 1948) 33 UNTS 261 (Specialized Agencies Convention).

D. $v$ Global Fund to Fight AIDs, Tuberculosis and Malaria, ILOAT Judgment No 4073 (2019).

Group of Eight (G8) and European Union, 'G8 Communiqué Genova 2001' (Ministry of Foreign Affairs of Japan, 2001) <https://www.mofa.go.jp/policy/economy/sum$\mathrm{mit} / 2001 /$ communique.html $>$ accessed on 2 February 2020.

Group of Eight (G8) and European Union, 'G8 Communiqué Okinawa 200o' (Ministry of Foreign Affairs of Japan, 23 July 200o) < https://www.mofa.go.jp/policy/economy/ summit/200o/documents/communique.html > accessed on 2 February 2020.

International Labour Office, 'Matters relating to the Administrative Tribunal of the ILO' (International Labour Organization, 2008) <https://www.ilo.org/wcmsp5/ groups/public/---ed_norm/---relconf/documents/meetingdocument/ wcms_100042.pdf > accessed on 2 February 2020.

Ayoub et al. $v$ International Labour Organisation, ILOAT Judgment No 832 (1987).

J. (No 2) v Global Fund to Fight AIDS, Tuberculosis and Malaria, ILOAT Judgment No 4074 (2019).

M. F. A. A. v Global Fund to Fight AIDs, Tuberculosis and Malaria, ILOAT Judgment No 3422 (2015).

Otis L, 'Review of Employee Grievance and Dispute Resolution System of the Global Fund to Fight Aids, Tuberculosis and Malaria' (August 2016, Unpublished).

R. M. (No 2) v Global Fund to Fight AIDS, Tuberculosis and Malaria, ILOAT Judgment No 3924 (2018).

Statute of the Administrative Tribunal of the International Labour Organization (ILOAT) < https://www.ilo.org/tribunal/about-us/WCMS_249194/lang--en/index .htm $>$ accessed on 2 February 2020.

The Global Fund, 'Constituencies' (The Global Fund) <https://www.theglobalfund. org/en/board/constituencies/> accessed 28 November 2019.

The Global Fund, 'Global Fund Agreement on Privileges and Immunities Enters into Force' (The Global Fund) <https:/www.theglobalfund.org/en/news/201904-17-global-fund-agreement-on-privileges-and-immunities-enters-into-force/> accessed 24 November 2019.

The Global Fund, 'Overview' (The Global Fund) <https://www.theglobalfund.org/en/ overview/> accessed 21 November 2019.

The Global Fund, 'Report of the Governance and Partnership Committee' (The Global Fund, 2003) < https://www.theglobalfund.org/media/2923/bmo5_07gpc_report_en .pdf $>$ accessed on 2 February 2020.

The Global Fund, 'Report of the Governance and Partnership Committee' (The Global Fund, 2004) <https://www.theglobalfund.org/media/3395/bmo8_07gpc_report _en.pdf $>$ accessed on 2 February 2020. 
The Global Fund, 'Results \& Impacts' (The Global Fund) < https://www.theglobalfund. org/en/impact/> accessed 10 February 2020.

The Global Fund, 'The Framework Document' (The Global Fund, 2001) <https://www .theglobalfund.org/media/6o19/core_globalfund_framework_en.pdf $>$ accessed 21 October 2020.

The Global Fund, 'The Global Fund Strategy 2017-2022' (The Global Fund) <https:// www.theglobalfund.org/media/2531/core_globalfundstrategy2017-2022_strategy _en.pdf $>$ accessed 24 November 2019.

The Global Fund, Board Decision GF/Bo2/DPo6, 22 April 2002.

The Global Fund, Board Decision GF/Bo2/DP10, 22 April 2002.

The Global Fund, Board Decision GF/B16/DP21, 13 November 2007.

The Global Fund, Board Decision GF/B17/EDPo8/16, 18 October 2008.

The Global Fund, Board Decision GF/B20/EDPo4, 14 December 2009.

The Global Fund, Bylaws of the Global Fund to Fight AIDs, Tuberculosis and Malaria (Approved 28 January 2016 and amended 14 November 2017) <https:// www.theglobalfund.org/media/6007/core_globalfund_bylaws_en.pdf?u $=637066575610000000>$ accessed 22 November 2020 .

United States Federal Register 'Executive Order 13395-Designating the Global Fund To Fight AIDs, Tuberculosis and Malaria as a Public International Organization Entitled To Enjoy Certain Privileges, Exemptions, and Immunities' (United States Federal Register, 13 January 2006) < https://www.federalregister.gov/documents/2006/01/19/06-554/designating-the-global-fund-to-fight-aids-tuberculosisand-malaria-as-a-public-international $>$ accessed 23 November 2019.

United Nations General Assembly Res S-26/2 (27 June 2001) UN Doc A/RES/S-26/2.

United Nations General Assembly Res 64/122 (16 December 2009) UN Doc A/RES/ $64 / 122$. 